\title{
Mitigation of Ethylene-promoted Leaf Senescence by a Natural Lipid, Lysophosphatidylethanolamine
}

\author{
Mustafa Özgen, ${ }^{1,2}$ Sookhee Park, ${ }^{1}$ and Jiwan P. Palta ${ }^{3}$ \\ Department of Horticulture, 1575 Linden Drive, University of Wisconsin, \\ Madison, WI 53706-1590
}

Additional index words. ethylene, phospholipids, lysophospholipids, LPE, chlorophyll, tissue culture, micropropagation, potato, Solanum tuberosum L., epinasty, apical dominance, shoot growth, axillary shoot formation, aging

\begin{abstract}
Mitigation of ethylene promoted leaf senescence by lysophosphatidylethanolamine (LPE) was studied. Micropropagated 'Russet Burbank' potato (Solanum tuberosum L.,) plantlets were grown on MS media in sterile culture tubes. After 2 weeks of growth, tubes were sealed and ethylene gas was applied to obtain $5 \mathrm{~nL} \cdot \mathrm{L}^{-1}$ final concentration in the culture tubes. Observations and measurements were taken two weeks after ethylene injection. Potato plantlets treated with ethylene showed severe leaf senescence symptoms such as epinasty, lack of growth, yellowing and axillary shoot formation. These observations indicate that apical dominance has been lost with ethylene treatment. The same experiment was repeated with different concentrations of LPE in the MS medium. Inclusion of 50 or $100 \mathrm{mg} \cdot \mathrm{L}^{-1}$ of LPE in the medium mitigated the damage normally caused by applied ethylene. Leaves of plantlets exposed simultaneously to LPE and ethylene had significantly higher chlorophyll content and more healthy leaves compared to plantlets grown on medium lacking LPE. Results of this study suggest that LPE may have the potential to retard ethylene-promoted leaf senescence and may mitigate ethylene induced loss in apical dominance of micropropagated potato plantlets.
\end{abstract}

Lipids are known to be important in membrane structure and energy balance. It is now evident that lipids and lipid-derived metabolites also play a role in critical cellular processes. Studies have shown that membrane lipid-based signaling mediated by phospholipases, such as phospholipase $\mathrm{A}_{2}\left(\mathrm{PLA}_{2}\right)$, phospholipase $\mathrm{C}$ (PLC), and phospholipase D (PLD) and their products constitutes a crucial step in plant growth and development (Exton, 1994; Liscovitch and Cantley, 1994; Nishizuka, 1992; Scherer, 1996; Ryu et al., 1997; Wang, 1999). Substances classified among lipids (vitamins and their precursors, and a number of hormones) have intense biological activity. For example, PLA -derived lysophospholipids were found to act as growth regulators that retard senescence of plant tissues (Farag and Palta, 1993; Ryu et al., 1997; Kaur and Palta, 1997; Ozgen et. al., 2005). Interestingly, PLA 2 products such as lysophosphatidylethanolamine (LPE) inhibited the activity of PLD (Ryu et al., 1997), a key enzyme thought to be responsible for membrane lipid breakdown leading to plant senescence (Ryu et al., 1997; Thompson, 1988). Ryu et al. (1997) concluded that lysophospholipids such as LPE serve as signaling molecule in retarding plant senescence. Foliar applications of LPE have also been found to retard senescence of in intact or detached leaves, flowers, and fruits (Farag and

Received for publication 29 Nov. 2004. Accepted for publication 8 Mar. 2005.

${ }^{1}$ Former graduate research assistant.

${ }^{2}$ Current address: Department of Horticulture, University of Gaziosmanpasa, Tasliciftlik Tokat, 60240, Turkey.

${ }^{3}$ Professor. To whom reprint request should be addressed; e-mail.jppalta@wisc.edu.
Murashige and Skoog (1962), with pH adjusted to $5.6 \pm 0.02$. Test tubes were then filled with 10 $\mathrm{mL}$ of media and capped before autoclaving at $132^{\circ} \mathrm{C}$ for $15 \mathrm{~min}$. LPE containing culture tubes were prepared by adding sterile LPE solutions with three different concentrations $0,25,50$ and $100 \mathrm{mg} \cdot \mathrm{L}^{-1}$ when the medium had cooled to about $70^{\circ} \mathrm{C}$. Stem cuttings of potato plantlets were then, micropropagated in these culture tubes. The 2nd and 3rd nodes of one month old micropropagated 'Russet Burbank' potato (Solanum tuberosum L.) plantlets grown on MS medium were excised as single node cuttings and returned to sterile culture tubes $(20 \times 150$ mm, Pyrex no. 9820) containing MS medium with or without LPE.

LPE derived from egg lecithin was used in our experiments and was obtained from Doosan Serdary Research Lab (Englewood, N.J.). LPE was suspended in water by using a sonicator (Sonic Dismembrator model 550; Fisher Scientific, Pittsburgh, Pa.).

Leaf senescence was stimulated by the treatment with exogenous ethylene after 2 weeks of growth. Tubes were sealed and ethylene gas was applied to obtain $5 \mathrm{~nL} \cdot \mathrm{L}^{-1}$ final concentration in the culture tubes. The study was conducted in two steps: In step 1, the damaging effects of ethylene on the plantlets were observed to confirm that the expected action of ethylene was evident in our system. In step 2, the potential retardation of leaf senescence by different concentrations of LPE was assessed. Observations were taken on axillary bud growth, leaf chlorophyll content and number of healthy leaves 2 weeks after ethylene injection.

Cultures were arranged in a randomized complete block design under continuous light with about $60 \mu \mathrm{mol} \cdot \mathrm{m}^{-2} \cdot \mathrm{s}^{-1}$ photosynthetic photonflux from cool white fluorescent lamps. Each treatment consisted of 15 plantlets. Experiments were repeated three times and similar results were obtained. Results from one experiment are summarized here.

Chlorophyll determination. Leaf disk samples from five plantlets in each of three replications were collected for chlorophyll extraction. Samples were incubated in vials containing $10 \mathrm{~mL}$ of absolute methanol. Vials were continuously shaken in a covered water bath at ambient temperature to facilitate chlorophyll extraction. Absorbance was read at 650 and $665 \mathrm{~nm}$ and chlorophyll concentration was calculated (25.5 [A650] + 4.0 [A665]) as mg chlorophyll/g fresh weight (Crafts-Brandner et al., 1984; Holden, 1976).

Data collection. In step 1 of the experiment, micropropagated potato plantlets grown on regular MS media were incubated in 0 and 5 $\mathrm{nL} \cdot \mathrm{L}^{-1}$ ethylene concentrations. The number of axillary buds and healthy (no epinastic appearance) leaves were counted after two weeks of incubation. In stage 2 of the experiment, single node cuttings of potato plantlets were grown on different concentrations of LPE containing media. After two weeks of growth, these plantlets were incubated in $5 \mathrm{~nL} \cdot \mathrm{L}^{-1}$ ethylene concentrations. Two weeks later, the number of axillary shoots and healthy leaves were counted and chlorophyll content of leaves was determined. 
Table 1. Influence of ethylene, on micropropagated potato plantlets. Tubes were injected with either 5 $\mathrm{nL} \cdot \mathrm{L}^{-1}$ ethylene or air. The number of axillary shoots and healthy leaves for each plantlet were counted 2 weeks after injection.

\begin{tabular}{lccc}
\hline & $\begin{array}{c}\text { Axillary shoots } \\
\text { (no.) }\end{array}$ & $\begin{array}{c}\text { Healthy leaves } \\
\text { Treatment }\end{array}$ & $\begin{array}{c}\text { Healthy leaves } \\
(\%)\end{array}$ \\
\hline Untreated control & 0.87 & 6.93 & 92.6 \\
Ethylene & 3.67 & 2.80 & 39.8 \\
Significance & $* *$ & $* *$ & $* *$ \\
\hline
\end{tabular}

${ }^{* *}$ Significantly different from control at $P \leq 0.01$ by $t$ test.

Table 2. Influence of LPE on ethylene promoted senescence of micropropagated potato plantlets. Tubes were injected $5 \mathrm{~nL} \cdot \mathrm{L}^{-1}$ ethylene and axillary shoots, leaf growth and chlorophyll content measurements were taken 2 weeks after ethylene injection.

\begin{tabular}{lccc}
\hline $\begin{array}{l}\text { LPE concn } \\
\left(\mathrm{mg} \cdot \mathrm{L}^{-1}\right)\end{array}$ & $\begin{array}{c}\text { Axillary shoots } \\
(\text { no. })\end{array}$ & $\begin{array}{c}\text { Healthy leaves } \\
(\text { no. })\end{array}$ & $\begin{array}{c}\text { Chlorophyll concn } \\
\left(\mathrm{mg}^{-1} \mathrm{~g}^{-1} \mathrm{fresh} \mathrm{wt}\right)\end{array}$ \\
\hline 0 (with ethylene) & $3.53 \mathrm{a}^{\mathrm{z}}$ & $2.73 \mathrm{c}$ & $0.45 \mathrm{~d}$ \\
25 & $1.87 \mathrm{~b}$ & $4.60 \mathrm{~b}$ & $0.63 \mathrm{c}$ \\
50 & $1.07 \mathrm{bc}$ & $6.27 \mathrm{ab}$ & $0.89 \mathrm{ab}$ \\
100 & $1.67 \mathrm{bc}$ & $5.80 \mathrm{ab}$ & $0.82 \mathrm{~b}$ \\
0 (without ethylene) & $0.73 \mathrm{c}$ & $6.73 \mathrm{a}$ & $1.02 \mathrm{a}$ \\
\hline
\end{tabular}

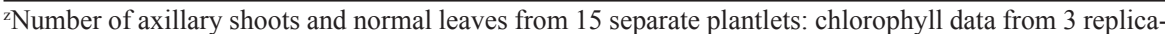
tions of composite samples of 5 plantlets. Means were compared by Fisher's protected LSD $(P<00.05)$; within each column means followed by the same letter do not differ significantly.

\section{Results}

Effect of ethylene on leaf senescence. Exposure to ethylene in step 1 of the experiment significantly affected potato plantlets in the culture tubes (Table 1). Potato plantlets treated with $5 \mathrm{~nL} \cdot \mathrm{L}^{-1}$ ethylene showed severe leaf senescence symptoms including thickened stems and leaves, axillary shoot growth, lack of growth, yellowing and epinasty (curling and bending downward of leaves) after two weeks. About $60 \%$ of the leaves of each plantlet were damaged by exposure to ethylene. Ethylene application also resulted in formation of an average of 3.7 axillary shoots per plantlet while untreated control plants had only 0.9 axillary shoots per plantlet.

Effect of LPE on ethylene-promoted leaf senescence. Incorporation of LPE into the rooting medium mitigated ethylene-promoted leaf senescence in micropropagated potato plantlets (Table 2). Plantlets grown in medium containing 50 or $100 \mathrm{mg} \cdot \mathrm{L}^{-1} \mathrm{LPE}$ had showed significantly higher chlorophyll content compared to control and plant grown on medium containing $25 \mathrm{mg} \cdot \mathrm{L}^{-1} \mathrm{LPE}$, after 2 weeks of ethylene exposure. Also, these plantlets had significantly more healthy leaves and less axillary shoot formation compared to plantlets grown in medium lacking LPE. Plantlets grown on medium containing $50 \mathrm{mg} \cdot \mathrm{L}^{-1} \mathrm{LPE}$ had three times less axillary shoot formation, more than twice the number of healthy leaves and $98 \%$ higher chlorophyll content in their leaves than plantlets grown on medium lacking LPE but exposed to ethylene.

\section{Discussion}

Application of exogenous ethylene to tubes containing micropropagated potato plantlets had effects that were expected based on literature: epinasty, yellowing and lack of growth. However, potato plantlets grown on medium containing 50 or $100 \mathrm{mg} \cdot \mathrm{L}^{-1}$ of LPE showed dramatically less damage typical of ethylene exposure. Results from this and previous studies (Farag and Palta, 1993; Kaur and Palta, 1997; Ozgen et. al., 2005; Ryu etal., 1997)demonstrate that the protective effect of LPE is concentration dependent. In the current study, concentrations of 50 and $100 \mathrm{mg} \cdot \mathrm{L}^{-1} \mathrm{LPE}$ protected against ethylene damage while lower concentrations did not and higher concentrations produced no toxic effects (data not shown). Furthermore ethylene treatment resulted in the formation of axillary shoots (Table1) suggesting that ethylene, when introduced in the environment of tissue cultured plantlets, can cause a loss in the apical dominance. Our results show that this loss in the apical dominance by ethylene was mitigated by the presence of LPE in the media (Table 2). Similar observations on axillary shoot formation, in tissue cultured plantlets, have been made when shoot apex is injured due to calcium deficiency (Busse et al., 2004; Ozgen and Palta, 2003). Results of the present study suggest that inclusion of LPE in the media to reduce the incidence of axillary shoot growth may have value in the maintenance of healthy shoot cultures.

The exact mode of action of LPE is not known. However, in previous studies, we established that LPE maintains plant cell health by protecting membranes during senescence and aging presumably by regulating PLD activity in a highly specific manner (Ryu et al., 1997). PLD expression levels are positively correlated with the rate of leaf senescence (Ryu and Wang, 1995). Therefore, it is reasonable to speculate that the protective effects of LPE against damage due to ethylene exposure drives from the inhibitory effect of LPE on the PLD enzyme. Results from this study have important implications based in part on the fact that, for the first time, the action of LPE absorbed through the root system has been shown to parallel that of foliar application.

\section{Literature Cited}

Abeles, F.B.,P.W.Morgan, and M.E. Saltveit, Jr. 1992. Ethylene in plant physiology. 2nd ed. Academic press, San Diego.

Busse, J.S., S. Ozgen, and J.P. Palta. 2004. Influence of root zone calcium on the maintenance of potato shoot apical dominance. HortScience 39:776.

Crafts-Brandner, S.J., F.E. Below, J.E. Harper, and R.H. Hageman. 1984. Effects of pod removal on metabolism and senescence of nodulating and nonodulating soybean isolines. II. Enzymes and chlorophyll. Plant Physiol. 75:318-322.

Exton, J.H. 1994. Mesenger molecules derived from membrane lipids. Curr. Opin. Cell Biol. 6:226-229.

Farag, K. and J.P. Palta. 1993. Use of lysophosphatidylethanolamine, a natural lipid, to retard tomato leaf and fruit senescence. Physiol. Plant 87:515-524.

Ferguson, C.H.R. and E.W Simon. 1973. Membrane lipids in senescing green tissues. J. Expt. Bot. 79:307.

Gepstein, S. and K.V. Thimman. 1987. The role of ethylene in the senescence of oat leaves. Plant Physiol. 68, 349-354.

Holden, M. 1976. Chlorophylls, p. 1-37. In: T.W. Goodwin (ed.). Chemistry and biochemistry of plant pigments. Academic Press, New York.

Kaur, N. and J.P. Palta. 1997. Postharvest dip in a natural lipid, lysophosphatidylethanolamine, may prolong vase life of snapdragon flowers. HortScience 32:888-890.

Lewington, R.J., M. Tablot, and E.W. Simon. 1967. Theyellowing of attached and detached cucumber cotyledons. J. Expt. Bot. 18:526-531.

Liscovitch, M. and L.C. Cantley. 1994. Lipid second messengers. Cell 77:329-334

Mattoo, K.M. and N. Aharoni. 1988. Ethylene and plant senescence, p. 241-279. In: L.D. Nooden, and A.C. Leopold (eds.). Senescence and aging in plants. Academic Press, San Diego.

Murashige, T. and F. Skoog. 1962. A revised medium for rapid growth and bioassay with tobacco tissue cultures. Physiol. Plant. 15:473-497.

Nishizuka, Y. 1992. Intercellular signaling by hydrolysis of phospholipids and activation of protein kinase C. Science 258:607-614.

Ozgen, M. and J.P. Palta. 2002. Mitigation of phytotoxicity of fungicide (Bravo) on cranberry fruits and flowers by lysophoshatidylethanolamine (LPE), a natural lipid. IHC 2002:232.

Ozgen, M., K. Farag, S. Ozgen, and J.P. Palta. 2005. Lysophosphatidylethanolamine accelerates color development and promotes shelf life of cranberries. HortScience 40:127-130.

Ozgen, S. and J.P. Palta. 2003. Root zone calcium has a dramatic influence on the growth of potato apical meristem and maintenance of apical dominance. Amer. J. Potato Res. 81:79.

Ryu, S.B. and X. Wang. 1995. Expression of phospholipase D during castor bean leaf senescence. Plant Physiol. 108:713-719.

Ryu, S.B., B.H. Karlsson, M. Ozgen, and J.P. Palta. 1997. Inhibition of phospholipase D by lysophosphatidylethanolamine, a lipid-derived senescence retardant. Proc. Natl. Acad. Sci. 94:12717-12721.

Scherer, G.F.E. 1996. Phospholipid signalling and lipid derived second messengers in plants. Plant Growth Regulat. 18:125-133.

Thompson, J.E. 1988. The molecular basis for membrane deterioration during senescence, $p$. 51-83. In: L.D. Nooden, and A.Q. Leopold (eds.). Senescence and aging in plants. Academic press, New York.

Wang, X. 1999. The role of phospholipase D in signaling Cascade. Plant Physiol. 120:645-651. 